\title{
Nutritional efficiency of feed restricted F1 Holstein/Zebu cows during the middle third of lactation
}

\author{
Pedro Felipe Santana', Vicente Ribeiro Rocha Júnior ${ }^{1,2, *}$, José Reinaldo Mendes Ruas ${ }^{1,2}$, \\ Flávio Pinto Monção', Luana Alcântara Borges', Thaís Eleonora Santos Sousa', Fredson Vieira e Silva', \\ Walber de Oliveira Rabelo ${ }^{1}$, Cinara da Cunha Siqueira Carvalho ${ }^{1}$ and Eleuza Clarete Junqueira de Sales ${ }^{1}$
}

${ }^{*}$ Corresponding Author: Vicente Ribeiro Rocha Júnio
Tel: +55-38-99983-8240, Fax: +55- 38-3821-2756,

E-mail: vicente.rocha@unimontes.br

${ }^{1}$ Department of Animal Science and Technology, State University of Montes Claros, Avenue Reinaldo Viana, Janaúba, MG 2630, Brazil

${ }^{2}$ National Institute of Science and Technology -INCT Animal Science Member, Brasília, 71605-001, Brazil

ORCID

Pedro Felipe Santana

https://orcid.org/0000-0003-3287-2375

Vicente Ribeiro Rocha Júnior

https://orcid.org/0000-0002-0721-1981

José Reinaldo Mendes Ruas

https://orcid.org/0000-0002-8824-2332

Flávio Pinto Monção

https://orcid.org/0000-0002-9821-0107

Luana Alcântara Borges

https://orcid.org/0000-0001-5191-1486

Thaís Eleonora Santos Sousa

https://orcid.org/0000-0002-0846-4198

Fredson Vieira e Silva

https://orcid.org/0000-0003-4341-0635

Walber de Oliveira Rabelo

https://orcid.org/0000-0001-8071-2494

Cinara da Cunha Siqueira Carvalho

https://orcid.org/0000-0002-3876-209X

Eleuza Clarete Junqueira de Sales

https://orcid.org/0000-0002-6177-5278

Submitted Oct 24, 2018; Revised Jan 13, 2019 ; Accepted Apr 30, 2019
Objective: The objective of this study was to evaluate the effects of different levels of quantitative feed restriction on nutrient intake and digestibility, nitrogen balance, efficiency and feeding behavior, and productive performance in F1 Holstein/Zebu cows during the middle third of their lactation.

Methods: Sixty F1 Holstein/Zebu cows with $111.5 \pm 11.75$ days of lactation and an initial body weight (BW) of $499 \pm 30 \mathrm{~kg}$ (mean \pm standard error of the mean) were used. The experimental design was completely randomized with the following diet levels of feed restriction: 3.39\%, $2.75 \%, 2.50 \%, 2.25 \%$, and $2.00 \%$ of BW, with 12 replications for each level. The experiment lasted for 63 days, of which each period lasted 21 days with the first 16 days for diet adaptation followed by 5 days for collection of data and samples.

Results: For each 1\% of BW diet restriction, there was a decrease in dry matter intake of 5.26 $\mathrm{kg} / \mathrm{d}(\mathrm{p}<0.01)$. There was no difference in daily milk production $(\mathrm{p}=0.09)$ under the restriction levels of $3.39 \%$ to $2.0 \%$ of BW. When corrected for $3.5 \%$ fat, milk production declined $(p=0.05) 3.46 \mathrm{~kg} / \mathrm{d}$ for each percentage unit of feed restriction.

Conclusion: Restricting the feed supply for F1 Holstein/Zebu cows in the middle third of their lactation period altered nutrient intake, nitrogen balance and ingestive behavior but did not affect milk production or feed efficiency. However, considering the observed BW loss and decrease in milk production corrected for 3.5\% fat, restriction of no less than $2.5 \%$ $\mathrm{BW}$ is recommended.

Keywords: Dairy Cattle; Feeding Time; Milk Production; Nitrogen Balance; Plasma Urea Nitrogen

\section{INTRODUCTION}

The dairy industry has a substantial contribution to the Brazilian agribusiness and most of the milk that is produced is from crossbred Holstein/Zebu cows [1]. These animals are used because of their consistent ability to maintain high levels of performance, with no changes in management, as well as their rusticity and adaptability to changes that occur in tropical environments [2].

Milk production (MP) in Brazil has nutritional value, and the use of forage plants whose supply and nutritional value changes considerably throughout the year, mainly during the dry season, affecting the animals' performance [3]. One alternative used by producers to maintain MP and to ensure its permanence is the strategic use of feedlots for animals whose food costs can have a negative impact on production.

Feed restriction may be an alternative that reduces production costs and increases the feed efficiency of the cattle, as reported by Keogh et al [4]. However, there is still little knowl- 
edge regarding the effects of feed restriction on nutritional, productive and behavioral parameters of crossbred Holstein/ Zebu cows during the middle third of the lactation period in the literature. According to Schütz et al [5], restriction of dietary supply in lactating cows can trigger rapid mobilization of body tissues for maintenance of normal bodily functions and can also affect the productive and reproductive activities of the animal, causing adaptive and metabolic body changes. There may also be a reduction in MP [6] as well as in fat, protein and stability $[7,8]$ beginning the fifth day of restriction. There may also be an increase in the somatic cell count [9]. However, the results may vary depending on the severity, duration and type of feed restriction [6]. In addition to the lactation phase, it is important to study the best level of this restriction for the animals and to relate these results to production [2].

The objective of this study was to evaluate the effects of different levels of quantitative food restriction on the nutrient intake and digestibility, nitrogen balance, MP, feed efficiency, and ingestive behavior in F1 Holstein/Zebu cows during the middle third of the lactation period.

\section{MATERIALS AND METHODS}

\section{Animal care and location}

All procedures involving animals was approved by the institutional committee on animal use (protocol number 138/ 2017). The study was conducted at the Experimental Farm of Unimontes, GPS coordinates: latitude $15^{\circ} 52^{\prime} 38^{\prime \prime}$ S, longitude $43^{\circ} 20^{\prime} 05^{\prime \prime} \mathrm{W}$.

\section{Animals, experimental design, diet and management}

Sixty F1 Holstein/Zebu cows in the middle third of their lactation periods ( $111.5 \pm 11.75$ days of lactation) with an initial body weight (BW) of $499 \pm 30 \mathrm{~kg}$ (mean \pm standard error of the mean) and a mean age of 6 years were used. The experimental design was completely randomized and had five feed restriction levels $(3.39 \%, 2.75 \%, 2.50 \%, 2.25 \%, 2.00 \%)$ with twelve cows used for each treatment. The diet supply, kg dry matter (DM)/d, defined as percentage of BW, were: ad libitum (3.39\%), allowing $5 \%$ of refusals relative to the amount of DM provided, and diets provided with $2.75 \%, 2.50 \%, 2.25 \%$, and $2.00 \%$ of BW. Before the trial period all cows received the experimental diet provided ad libitum for 14 days, with a goal of allowing the animals to adapt to the diet and management.

The diet (Table 1) was given based on the BW of each cow and in accordance with each treatment, maintaining roughage: concentrate ratio of 75:25 in the total DM of the diet. The diets were offered to the animals twice a day, at 8:00 am and at 3:00 pm, in a complete diet system. The roughage base for the diets was corn silage, which was weighed daily and then mixed into the concentrate.
Table 1. Chemical composition of ingredients and diet used during experimental period

\begin{tabular}{lccc}
\hline Items (g/kg DM) ${ }^{1)}$ & $\begin{array}{c}\text { Corn } \\
\text { silage }\end{array}$ & $\begin{array}{c}\text { Concentrated } \\
\text { mixture }\end{array}$ & Diet $^{2)}$ \\
\hline Dry matter & 447.7 & 925.9 & 567.2 \\
Organic matter & 961.2 & 922.3 & 951.5 \\
Crude protein & 72.4 & 218.3 & 108.8 \\
NDIN & 5.50 & 12.24 & 7.18 \\
ADIN & 0.93 & 0.75 & 0.89 \\
Ether extract & 25.1 & 28.3 & 25.9 \\
Non-fibrous carbohydrates & 283.4 & 371.7 & 305.5 \\
NDFap & 580.3 & 304.1 & 511.3 \\
Neutral detergente fiber & 307.4 & 72.2 & 248.6 \\
Lignin & 60.3 & 31.8 & 53.2 \\
Total digestible nutrients ${ }^{3)}$ & 606.4 & 734.2 & 638.4 \\
\hline
\end{tabular}

DM, dry matter; NDIN, neutral detergent insoluble nitrogen; ADIN, acid detergent insoluble nitrogen; NDFap, neutral detergent fiber corrected for ash and protein.

1) Nutrient in dry basis (grams per kilogram).

2) Diet used during the experiment (e.g., diet consisted of $75 \%$ corn silage and $25 \%$ concentrate in the total dry matter).

${ }^{3)} \mathrm{NRC}[14]$.

The cows were kept in individual pens with an area of approximately $26 \mathrm{~m}^{2}$, equipped with troughs (1 linear meter) and drinkers (capacity of 200 liters). Milking was performed mechanically twice a day, at 7:00 am and 2:00 pm, with the calf present to stimulate milk letdown. Immediately after milking, the calves remained with the cows to feed from the residual milk.

The experiment lasted for 63 days that were divided in three period. Each period lasted 21 days with the first 16 days for adaptation of the animals the diet (diet supply levels) followed by 5 days for collection of data and samples.

\section{Intake and apparent digestibility evaluations}

Intake was evaluated daily by weighing the feed provided and the refusals of the animals. Samples of the offered diets and the refusals were stored at $-20^{\circ} \mathrm{C}$ for further analysis.

Samples of diets, concentrate ingredients, refusals, and feces were analyzed to evaluate feed intake and digestibility. The samples were analyzed for DM (method 967.03), ash (method 942.05), crude protein (CP; method 981.10), and ether extract (EE; method 920.39) according to the recommendations of the AOAC [10]. The contents of the neutral detergent fiber were corrected for ash and protein (NDFap) using heat-stable alpha-amylase without sodium sulfite and acid detergent fiber (ADF) were determined as described by Mertens [11] and Licitra et al [12]. Lignin content was determined by treating the ADF residue with sulfuric acid at 72\% [13]. Non-fiber carbohydrate (NFC) contents were calculated as described by Detmann et al [13]: NFC (g/kg) = 100-ash-EE-NDFap-CP; where ash is mineral matter (crude ash).

The total digestible nutrients (TDN) were estimated using 
the formula proposed by NRC [14]. To analyze the indigestible NDF, feed samples were placed in nonwoven fabric bags $\left(20 \mathrm{mg} / \mathrm{cm}^{2}\right)$ and incubated in the rumen for 288 hours ([13]; method INCT-CA F-008/1). Two adult crossbred cattle cannulated in the rumen and weighing $480 \pm 30 \mathrm{~kg}$, with a mean age of 8 years were used for sample incubation. To determine the digestibility of each fraction, we used the following equation: ([ingested nutrient amount - amount nutrient excreted in the feces] $\times 100$ ) / ingested nutrient amount.

\section{Nitrogen balance and nitrogen concentration in the milk, blood, and urine}

We collected samples of milk from each animal twice a day during the last five days of the trial period, and we measured the total amount of milk produced in the morning and afternoon. Fifty milliliters of the collected samples were added to a bottle containing the preservative Bronopol and then analyzed for milk urea nitrogen (MUN). The concentrations of MUN were determined by enzymatic and spectrophotometric methods of transreflectance using a ChemSpeck 150 (Uniontown, $\mathrm{OH}, \mathrm{USA}$ ).

Blood samples were collected from the coccygeal vein into vacuum tubes containing sodium fluoride and potassium oxalate (Glistab anticoagulant; Labtest Diagnóstica S.A., Lagoa Santa, Brazil) 4 hours after the morning feeding on the last day of the experimental period. The samples were centrifuged at 4,000 rpm for $20 \mathrm{~min}$ and the serum obtained was conditioned in Eppendorf tubes and frozen at $-18^{\circ} \mathrm{C}$ for further analysis. Plasma urea concentrations were determined by a colorimetric enzymatic method using commercial kits (Ureia 500, Doles Reagents; Panamá, Brazil).

Urine spot samples were obtained during the experimental period, approximately four hours after feeding, during spontaneous urination. An aliquot of $10 \mathrm{~mL}$ of the urine sample was filtered and immediately diluted in $40 \mathrm{~mL}$ of $\mathrm{H}_{2} \mathrm{SO}_{4}, 0.036$ $\mathrm{N}$ for later analysis of urea and creatinine, as described by Oliveira et al [15]. The samples were then transferred to Eppendorf tubes and analyzed for urea content using the same method as was used for the blood samples. The end-point method determined the creatinine by means of picrate and acidifying with enzymatic methods. Quantification of the daily urinary volume of each animal was obtained by multiplying the respective BW by the amount of creatinine excreted daily, and then dividing the product by the creatinine concentration $(\mathrm{mg} / \mathrm{L})$ in the spot sample. The average value of $24.04(\mathrm{mg} / \mathrm{kg} \mathrm{BW})$ was used, according to Chizzotti et al [16], to obtain the total daily creatinine excretion.

To perform the nitrogen balance calculation, the ingested amount of nitrogen ( $\mathrm{N}$-ingested; $\mathrm{g} / \mathrm{d}$ ) and the amount excreted in the feces (N-feces; $\mathrm{g} / \mathrm{d})$, urine (N-urine; $\mathrm{g} / \mathrm{d})$, and milk (Nmilk; g/d) were used. The nitrogen utilization efficiency (NUE) of the diet was calculated by dividing the concentration of the nitrogen retained in the milk by the nitrogen intake in $\mathrm{kg} / \mathrm{d}$ [17].

Feed efficiency was calculated by dividing the average milk yield $(\mathrm{kg} / \mathrm{d})$ by the DM intake $(\mathrm{kg} / \mathrm{d})$ [18]. The evaluation of costs with concentrates, roughage and total diet were calculated by multiplying the intake by the respective value of each fraction, which was calculated according to its composition and the price of each ingredient [19]. The values per kilogram of the diet ingredients were as follows: corn silage was $\$ 0.05$ and concentrate was $\$ 0.46$. The values are expressed in US dollars, considering the ratio of $\mathrm{R} \$ 3.5$ (real) for every US\$1.

\section{Feeding behavior evaluations}

The feeding behavior was assessed in the last 2 days of the trial period. For the evaluation of the feeding behavior, all animals were observed visually for $24 \mathrm{~h}$, and the observations were recorded at 5-min intervals, which included eating, ruminating, and idle times [20]. On the same day, three observations were made for each animal: in the morning, at noontime, and at night. Data were collected by trained observers using digital timers. During the nocturnal observation, the environment was kept under artificial light. Feeding behavior variables (eating, ruminating, and idle times) were obtained by using equations adapted from Bürger et al [21]. The number of chews per ruminal bolus and the time spent ruminating each bolus were recorded during the observation periods. The number of bolus ruminated daily was calculated by dividing the total rumination time ( $\mathrm{min}$ ) by the average time spent to ruminate one bolus.

\section{Production, performance and body condition scores} During the trial period, the MP was recorded per cow. The MP was corrected for the fat content (FC) 3.5\% using the equation proposed by Sklan et al [22]: MP 3.5\% $=\mathrm{MP} \times(0.432+$ $0.163 \times \mathrm{FC})$.

To evaluate the BW of the animals, we used a mechanical scale. The animals were weighted at the beginning and end of the experiment. Body condition scores (BCS) were evaluated by a single technician weekly during the period. The BCS were also examined for three weeks further, following the end of the experimental period, to investigate the development of the animals. In the assessment of the BCS, the 1 to 5-point scale with 0.25 -point intervals was used, in which 1 represents a very lean cow and 5 a very fat cow [23].

\section{Statistical analysis}

The data was analyzed using the PROC MIXED procedure of SAS [24] (SAS Institute Inc., Cary, NC, USA). The model included treatment and period (time) as fixed effects. Results were reported as least squares means. Polynomial regressions were used to test the linear and quadratic changes affected due to the increasing feed restriction. Diagnostics concerning ho- 
mogeneity of the variances and the normality of the residuals were examined and were not of concern for the variables studied here. Significant differences was declared at $\mathrm{p}<0.05$.

\section{RESULTS}

\section{Intake and digestibility of nutrient}

For each 1\% BW of feed restriction the DM intake was reduced by $5.26 \mathrm{~kg} / \mathrm{d}(\mathrm{DMI}, \mathrm{p}<0.01)$, the CP by $0.61 \mathrm{~kg} / \mathrm{d}(\mathrm{CPI}$, $\mathrm{p}<0.01)$, the NFC by1.82 kg/d ( $<<0.01)$, the neutral detergent fiber corrected for ash and protein by $2.43 \mathrm{~kg} / \mathrm{d}$ (NDFap; $\mathrm{p}<$ $0.01)$ and the TDNs by $2.61 \mathrm{~kg} / \mathrm{d}(\mathrm{p}<0.01)$ (Table 2). The apparent digestibility of DM ( $\mathrm{p}=0.29), \mathrm{EE}(\mathrm{p}=0.11)$, NFC ( $\mathrm{p}$ $=0.49)$, NDFap $(p=0.11)$ and TDN $(p=0.39)$ was not differed with the feed restriction of the animals, with the averages being $59.20 \%, 82.35 \%, 76.87 \%, 54.50 \%$, and $61.93 \%$, respectively. There was a $19.06 \%$ increase in CP digestibility $(p=0.03)$ with feed restriction.

\section{Nitrogen balance and nitrogen concentration in the milk, blood, and urine}

Ingested nitrogen $(\mathrm{p}<0.01)$ and nitrogen excreted in milk ( $\mathrm{p}$ $=0.01)$ and feces $(\mathrm{p}<0.01)$ was linearly reduced with dietary restriction. There was a decrease of $45.76 \%$ in ingested nitrogen when the diet supply was limited from $3.39 \%$ to $2.00 \%$ of BW. Nitrogen losses in milk and feces were in the order of 19.57 and $61.20 \mathrm{~g} / \mathrm{d}$, respectively, per unit percentage reduction in supply. For nitrogen excreted in the urine, the means were adjusted to the quadratic regression model $(\mathrm{p}=0.05)$, with the highest concentration occurring at the restriction level of $3.05 \%$ of BW supply (Table 3 ). The nitrogen balance (nitrogen retained) was reduced $(\mathrm{p}<0.01)$ by $36.39 \mathrm{~g} / \mathrm{d}$ with the restriction in the diet supply of $3.39 \%$ to $2.0 \%$ of BW. It was verified that NUE was not altered with the restriction in the diet supply (mean $0.26 ; p=0.59$ ). The feed restriction of the cows did not modify the content of urea nitrogen present in the urine ( $\mathrm{p}=0.11)$ and milk $(\mathrm{p}=0.17)$, with averages being 7.99 and $15.86 \mathrm{mg} / \mathrm{dL}$, respectively. There was an increase of $3.66 \mathrm{mg} / \mathrm{dL}$ in the concentration of nitrogen in the plasma when the diet supply was reduced by $1 \%$.

\section{Feeding behavior evaluations}

Cows without restrictions in their diets spent $307.8 \mathrm{~min} / \mathrm{d}$ more eating when compared to animals with a restriction of $2.00 \%$ BW $(\mathrm{p}<0.01$; mean $132.6 \mathrm{~min} / \mathrm{d})$. There was a reduction of $225.7 \mathrm{~min} / \mathrm{d}, 9.48 \mathrm{~min} / \mathrm{kg} \mathrm{DM}(\mathrm{p}=0.02)$ and $20.09 \mathrm{~min} / \mathrm{kg}$ NDFap ( $\mathrm{p}=0.01)$ in the feeding time when restricted to $2.00 \%$ of BW (Table 4). For each $1 \%$ of feed restriction, there was a reduction of $107 \mathrm{~min} / \mathrm{d}$ in rumination time. When expressed as $\mathrm{min} / \mathrm{kg} \mathrm{DM}(\mathrm{p}=0.26)$ and $\mathrm{min} / \mathrm{kg}$ NDFap ( $=0.47)$, the rumination efficiency was not altered by the diet supply restriction, averaging $1.926 \mathrm{~min} / \mathrm{kg} \mathrm{DM}$ and $957.2 \mathrm{~min} / \mathrm{kg}$ NDFap. The number of bolus chews ( $\mathrm{p}=0.55)$, as well as chewing time in $\mathrm{min} / \mathrm{kg} \mathrm{DM}(\mathrm{p}=0.62)$ and $\mathrm{min} / \mathrm{kg}$ NDFap $(\mathrm{p}=0.39)$ did not change due to feed restriction in lactating cows. The number of chews per day $(\mathrm{p}=0.04)$ was reduced by $38.34 \%$

Table 2. Nutrient intake and digestibility in F1 Holstein/Zebu cows under quantitative feed restriction in the middle third of lactation

\begin{tabular}{|c|c|c|c|c|c|c|c|c|}
\hline \multirow{2}{*}{ Items } & \multicolumn{5}{|c|}{ Levels of restriction $(\% \mathrm{BW})^{1)}$} & \multirow{2}{*}{ SEM } & \multicolumn{2}{|c|}{$p$-value } \\
\hline & $3.39^{2)}$ & 2.75 & 2.50 & 2.25 & 2.00 & & Linear & Quad \\
\hline \multicolumn{9}{|l|}{ Intake } \\
\hline $\mathrm{DM}(\% \mathrm{BW})$ & 3.22 & 2.75 & 2.50 & 2.25 & 2.00 & 0.06 & $<0.01$ & 0.27 \\
\hline$C P(\mathrm{~kg} / \mathrm{d})^{\mathrm{b})}$ & 1.79 & 1.37 & 1.24 & 1.06 & 0.94 & 0.05 & $<0.01$ & 0.68 \\
\hline $\mathrm{EE}(\mathrm{kg} / \mathrm{d})^{\mathrm{c}}$ & 0.42 & 0.33 & 0.29 & 0.25 & 0.22 & 0.01 & $<0.01$ & 0.91 \\
\hline $\operatorname{NDFCP}(\mathrm{kg} / \mathrm{d})^{\mathrm{e})}$ & 7.77 & 6.42 & 5.83 & 4.98 & 4.42 & 0.22 & $<0.01$ & 0.40 \\
\hline $\operatorname{TDN}(\mathrm{kg} / \mathrm{d})^{f)}$ & 9.12 & 7.63 & 7.21 & 6.18 & 5.47 & 0.29 & $<0.01$ & 0.33 \\
\hline \multicolumn{9}{|c|}{ Nutrient digestibility (\%) } \\
\hline DM & 54.75 & 57.38 & 61.62 & 60.65 & 61.63 & 2.59 & 0.29 & 0.76 \\
\hline$\left(P^{g)}\right.$ & 51.88 & 48.15 & 59.25 & 55.46 & 61.77 & 2.63 & 0.03 & 0.12 \\
\hline $\mathrm{EE}$ & 77.55 & 83.75 & 85.17 & 83.23 & 82.09 & 2.25 & 0.11 & 0.11 \\
\hline
\end{tabular}

BW, body weight; SEM, standard error of the mean; p, probability; DM, dry matter; CP, crude protein; EE, ether extract; NFC, Non-fibrous carbohydrates; NDFap, neutral detergent fiber corrected for ash and protein; TDN, total digestible nutrients.

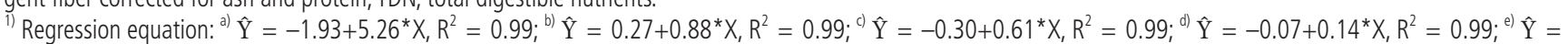
$\left.-1.08+1.82 * X, R^{2}=0.99 ;{ }^{*}\right) \hat{Y}=-0.394+2.43^{*} X, R^{2}=0.99 ;{ }^{9)} \hat{Y}=0.388+2.61^{*} X, R^{2}=0.98$, where $X$ is the level of food restriction; $R^{2}$ is the coefficient of determination; * significant by the $t$ test, at $1 \%$ probability.

${ }^{2)}$ Diet ad libitum, allowing $5 \%$ refusals regarding dry matter offer. 
Table 3. Balance and efficiency of nitrogen use in crossbred F1 Holstein/Zebu cows under quantitative feed restriction in the middle third of lactation

\begin{tabular}{|c|c|c|c|c|c|c|c|c|}
\hline \multirow{2}{*}{ Items } & \multicolumn{5}{|c|}{ Levels of restriction (\% BW $)^{1)}$} & \multirow{2}{*}{ SEM } & \multicolumn{2}{|c|}{$p$-value } \\
\hline & $3.39^{2)}$ & 2.75 & 2.50 & 2.25 & 2.00 & & Linear & Quad \\
\hline $\mathrm{N}$-ingested $(\mathrm{g} / \mathrm{d})^{\mathrm{a}}$ & 298.13 & 218.50 & 211.15 & 171.04 & 161.70 & 12.86 & $<0.01$ & 0.46 \\
\hline$N$-milk $(g / d)^{b)}$ & 69.13 & 56.72 & 55.72 & 48.89 & 40.24 & 4.47 & 0.01 & 0.52 \\
\hline$N$-feces $(g / d) c$ & 144.27 & 113.32 & 86.05 & 75.75 & 61.45 & 9.03 & $<0.01$ & 0.86 \\
\hline N-urine $(g / d)$ & 58.55 & 50.35 & 72.39 & 67.80 & 82.82 & 7.36 & 0.05 & 0.13 \\
\hline Nitrogen balance ${ }^{d)}(g / d)$ & 26.17 & -1.89 & -3.00 & -21.40 & -22.81 & 7.62 & $<0.01$ & 0.75 \\
\hline $\mathrm{NUE}^{\mathrm{e})}$ & 0.23 & 0.26 & 0.27 & 0.29 & 0.25 & 0.02 & 0.59 & 0.36 \\
\hline $\operatorname{UUN}(\mathrm{mg} / \mathrm{dL})^{f)}$ & 7.46 & 10.92 & 9.95 & 4.88 & 6.75 & 1.58 & 0.11 & 0.34 \\
\hline PUN (mg/dL) & 11.53 & 14.20 & 13.56 & 15.10 & 17.23 & 1.03 & 0.02 & 0.48 \\
\hline MUN (mg/dL) & 15.15 & 13.70 & 16.63 & 15.75 & 18.10 & 1.21 & 0.17 & 0.16 \\
\hline
\end{tabular}

BW, body weight; SEM, standard error of the mean; p, probability; N, nitrogen; NUE, nitrogen use efficiency; UUN, urine urea nitrogen; PUN, plasma urea nitrogen; MUN, milk urea nitrogen.

1) Regression equation: ${ }^{\text {a) }} \hat{Y}=-45.61+99.96^{*} X, R^{2}=0.97{ }^{\text {b) }} \hat{Y}=3.67+19.57^{*} X, R^{2}=0.96 ;{ }^{\text {c) }} \hat{Y}=-61.61+61.20^{*} X ; R^{2}=0.98 ;{ }^{\text {d) }} \hat{Y}=289.80-153.66^{*} X+25.13^{*} X^{2}$, $R^{2}=0.76 ;{ }^{e)} \hat{Y}=-98.41+36.39^{*} X, R^{2}=0.96 ;{ }^{f)} \hat{Y}=23.77-3.66^{*} X, R^{2}=0.87$ where $X$ is the level of food restriction; $R^{2}$ is the coefficient of determination; ${ }^{*}$ significant by the $t$ test, at $1 \%$ probability.

2) Diet ad libitum, allowing $5 \%$ refusals regarding dry matter offer.

Table 4. Feeding behavior of F1 Holstein/Zebu cows under quantitative feed restriction in the middle third of lactation

\begin{tabular}{|c|c|c|c|c|c|c|c|c|}
\hline \multirow{2}{*}{ Items } & \multicolumn{5}{|c|}{ Levels of restriction $(\% \mathrm{BW})^{1)}$} & \multirow{2}{*}{ SEM } & \multicolumn{2}{|c|}{$p$-value } \\
\hline & $3.39^{2)}$ & 2.75 & 2.50 & 2.25 & 2.00 & & Linear & Quad \\
\hline \multicolumn{9}{|l|}{ Feeding } \\
\hline $\min / d^{a)}$ & 440.4 & 240 & 204 & 153.6 & 132.6 & 28.2 & $<0.01$ & 0.09 \\
\hline $\min / \mathrm{kg} \mathrm{DM}^{\mathrm{b})}$ & 27.37 & 19.17 & 16.87 & 15.62 & 14.36 & 2.64 & 0.02 & 0.61 \\
\hline $\min / \mathrm{kg}$ NDFap ${ }^{c}$ & 55.69 & 37.5 & 33 & 30.56 & 28.08 & 5.16 & 0.01 & 0.32 \\
\hline \multicolumn{9}{|l|}{ Rumination } \\
\hline $\min / d^{d)}$ & 456.6 & 415.2 & 367.8 & 339 & 311.4 & 28.8 & 0.02 & 0.60 \\
\hline $\min / \mathrm{kg} \mathrm{DM}$ & 2,219 & 1,828 & 1,980 & 1,785 & 1,818 & 149 & 0.26 & 0.60 \\
\hline min/kg NDFap & 1,087 & 935 & 1,013 & 912 & 929 & 76 & 0.47 & 0.73 \\
\hline \multicolumn{9}{|l|}{ Chewing } \\
\hline number/bolus & 49.86 & 38.31 & 49.39 & 39.19 & 42.46 & 6.22 & 0.55 & 0.66 \\
\hline number/d ${ }^{\mathrm{e})}$ & 26,706 & 21,034 & 20,191 & 18,181 & 16,466 & 2,117 & 0.04 & 0.81 \\
\hline $\min / d^{f)}$ & 896.4 & 655.2 & 571.2 & 492.6 & 444 & 30 & $<0.01$ & 0.24 \\
\hline $\min / \mathrm{kg} \mathrm{DM}$ & 54.71 & 52.67 & 47.46 & 50.62 & 48.05 & 3.74 & 0.62 & 0.86 \\
\hline $\min / k g$ NDFap & 111.5 & 103 & 92.8 & 99 & 94 & 7.2 & 0.39 & 0.65 \\
\hline \multicolumn{9}{|l|}{ Idleness } \\
\hline $\min / d^{g)}$ & 543.6 & 784.8 & 868.8 & 947.4 & 996 & 30 & $<0.01$ & 0.26 \\
\hline
\end{tabular}

BW, body weight; SEM, standard error of the mean; p, probability; DM, dry matter; NDFap, neutral detergent fiber corrected for ashes and protein.

1) Regression equation: ${ }^{\text {a) }} \hat{Y}=-346.37+225.17^{*} X, R^{2}=0.96 ;{ }^{b)} \hat{Y}=-5.78+9.48^{*} X, R^{2}=0.95 i^{c} \hat{Y}=-14.83+20.09^{*} X, R^{2}=0.94 ;{ }^{d} \hat{Y}=100.61+107^{*} X, R^{2}=0.97 ;{ }^{\text {e) }}$ $\hat{Y}=-1809.76+7256.01{ }^{*} X, R^{2}=0.99{ }^{f)} \hat{Y}=-245+332.38^{*} X, R^{2}=0.99 ;{ }^{9)} \hat{Y}=1685-332.38 * X, R^{2}=0.99$ where $X$ is the level of food restriction; $R^{2}$ is the coefficient of determination; ${ }^{*}$ significant by the t test, at $1 \%$ probability.

${ }^{2)}$ Diet ad libitum, allowing $5 \%$ refusals regarding dry matter offer.

in the animals with a $2.0 \%$ restriction supply when compared to cows without restriction (26,706 chews/d). When expressed in $\mathrm{min} / \mathrm{d}$, the chewing time was reduced by $338.32 \mathrm{~min}$ for each $1 \%$ of diet restriction, and cows fed a $2.0 \%$ BW supply level spent less time $(444 \mathrm{~min} / \mathrm{d})$ for this activity. The idle time was $45.42 \%$ higher in these animals than in animals without any diet restriction (mean of $543.6 \mathrm{~min} / \mathrm{d}$ ). The number of feeding periods $(\mathrm{p}<0.01)$ decreased by $76.92 \%$ for the restricted animals. For each percentage unit of diet supply restriction, there was a reduction of 7.17 feedings/d (Table 5). The dura- tion of the feeding period $(\mathrm{p}=0.35)$ and rumination $(\mathrm{p}=0.35)$ was not influenced by feed restriction. An increase of 19.92 min for the duration of the idling period was observed in animals with a supply restriction of $2.0 \% \mathrm{BW}$. The feed efficiency of DM ( $\mathrm{p}=0.03)$ and NDFap $(\mathrm{p}=0.02)$ in grams/h increased linearly with the restriction of the diet supply.

\section{Production, performance, and body condition scores} There was no difference in daily milk production $(\mathrm{p}=0.09)$ with restriction in the diet supply to $3.39 \%$ to $2.0 \%$ of BW. 
Table 5. Number of periods and average time spent per period on the feeding, ruminating, and idle activities by F1 Holstein/Zebu cows under quantitative feed restriction in the middle third of lactation

\begin{tabular}{|c|c|c|c|c|c|c|c|c|}
\hline \multirow{2}{*}{ Items } & \multicolumn{5}{|c|}{ Levels of restriction $(\% \mathrm{BW})^{1)}$} & \multirow{2}{*}{ SEM } & \multicolumn{2}{|c|}{$p$-value } \\
\hline & $3.39^{2)}$ & 2.75 & 2.50 & 2.25 & 2.00 & & Linear & Quad \\
\hline \multicolumn{9}{|c|}{ Number of periods $(n / d)$} \\
\hline Feeding ${ }^{a}$ & 13.0 & 4.5 & 4.7 & 3.2 & 3.0 & 0.71 & $<0.01$ & 0.01 \\
\hline Ruminating & 14.5 & 12.75 & 12 & 13.5 & 12.75 & 1.19 & 0.65 & 0.42 \\
\hline Idling & 21 & 20.25 & 19.75 & 19.75 & 18.75 & 1.37 & 0.83 & 0.84 \\
\hline \multicolumn{9}{|c|}{ Time spent per period (min) } \\
\hline Feeding & 33.93 & 54.88 & 42.44 & 53.65 & 46.15 & 7.81 & 0.35 & 0.26 \\
\hline Ruminating & 31.96 & 33.09 & 34.47 & 25.04 & 24.54 & 4.25 & 0.35 & 0.21 \\
\hline Idling ${ }^{b)}$ & 26 & 39.14 & 45.64 & 47.96 & 53.98 & 3.4 & $<0.01$ & 0.81 \\
\hline \multicolumn{9}{|l|}{ Feed efficiency } \\
\hline $\mathrm{g} D M / h^{c)}$ & 2,361 & 3,210 & 3,804 & 3,912 & 4,239 & 381 & 0.03 & 0.80 \\
\hline g NDFap $/ h^{\text {d) }}$ & 1,154 & 1,641 & 1,945 & 2,000 & 2,167 & 193 & 0.02 & 0.71 \\
\hline \multicolumn{9}{|c|}{ Rumination efficiency } \\
\hline Boluses/d & 49.86 & 38.31 & 49.39 & 39.19 & 42.46 & 6.22 & 0.55 & 0.70 \\
\hline$g \mathrm{DM} / \mathrm{h}$ & 2,219 & 1,828 & 1,980 & 1,785 & 1,818 & 149 & 0.26 & 0.48 \\
\hline g NDFap/h & 1,087 & 935 & 1,013 & 912 & 929 & 76 & 0.47 & 0.66 \\
\hline
\end{tabular}

BW, body weight; SEM, standard error of the mean; $p$, probability; DM, dry matter; NDFap, neutral detergent fiber corrected for ashes and protein; $h$, hour.

${ }^{1)}$ Regression equation: $\left.{ }^{\text {a) }} \hat{Y}=-12.80+7.17{ }^{*} X, R^{2}=0.85 ;{ }^{\text {b) }} \hat{Y}=93.90-19.92^{*} X, R^{2}=0.99 ;{ }^{c}\right) \hat{Y}=7,044.02-1,372.74{ }^{*} X, R^{2}=0.98 ;{ }^{d)} \hat{Y}=3687.88-739.48 * X, R^{2}=$ 0.98 ; where $X$ is the level of food restriction; $R^{2}$ is the coefficient of determination; ${ }^{*}$ significant by the $t$ test, at $1 \%$ probability.

${ }^{2)}$ Diet ad libitum, allowing $5 \%$ refusals regarding dry matter offer.

When corrected for $3.5 \%$ fat, milk production decrease $(\mathrm{p}=$ $0.05) 3.46 \mathrm{~kg} / \mathrm{d}$ for each percentage unit of feed restriction (Table 6). It was verified that for each $1 \%$ of feed restriction the final BW of the cows in the middle third of their lactation period was reduced by $46.75 \mathrm{~kg}$, with the lowest values observed in animals with the highest level of restriction $(2.0 \%$, $438 \mathrm{~kg})$. The final BW differential in relation to the initial weight was not influenced by restriction $(\mathrm{p}=0.56)$, nor was the final BCS $(\mathrm{p}=0.65)$. Dietary restriction did not affect feed efficiency ( $\mathrm{p}=0.49$ ), with a mean of $0.93 \mathrm{~kg}$ of milk $/ \mathrm{kg}$ of DMI. Feed restriction of $3.39 \%$ BW to $2.0 \%$ reduced diet costs of \$ 3.25 to $\$ 1.77$.

\section{DISCUSSION}

The DMI is one of the main factors affecting animal health and performance [24]. According to the NRC, DMI is a function of the metabolic weight of the animal, week of lactation, and FC in milk and is estimated at $20.61 \mathrm{~g} / \mathrm{kg}$ of BW $(9.99$ $\mathrm{kg} / \mathrm{d}$ ) for crossbred cows. However, a voluntary DMI of 32.74 $\mathrm{g} / \mathrm{kg}$ of BW $(15.88 \mathrm{~kg} / \mathrm{d})$ during the middle third of the lactation period is a greater value than what is estimated by the NRC [14] for maintenance and production. This difference can be explained by the fact that the NRC calculates these estimates based on Holstein cows in temperate regions. Murta

Table 6. Performance and feed efficiency in F1 Holstein/Zebu cows under quantitative feed restriction in the middle third of lactation

\begin{tabular}{|c|c|c|c|c|c|c|c|c|}
\hline \multirow{2}{*}{ Items } & \multicolumn{5}{|c|}{ Levels of restriction (BW) ${ }^{1)}$} & \multirow{2}{*}{ SEM } & \multicolumn{2}{|c|}{ p-value } \\
\hline & $3.39^{2)}$ & 2.75 & 2.50 & 2.25 & 2.00 & & Linear & Quad \\
\hline Milk production (kg/d) & 13.05 & 11.60 & 10.70 & 10.67 & 8.26 & 1.10 & 0.09 & 0.47 \\
\hline Milk production corrected for 3.5 fat $(\mathrm{kg} / \mathrm{d})^{\mathrm{a})}$ & 13.61 & 11.30 & 11.30 & 10.27 & 8.32 & 1.10 & 0.05 & 0.59 \\
\hline Final body weight $(\mathrm{kg})^{\mathrm{b}}$ & 485 & 457 & 455 & 433 & 438 & 80 & $<0.01$ & 0.57 \\
\hline Final and initial body weight difference $(\mathrm{kg})$ & -24.25 & -25.04 & -56.31 & -52.92 & -69.94 & 23.04 & 0.56 & 0.66 \\
\hline Final body condition score & 3.81 & 3.81 & 3.88 & 3.69 & 3.63 & 0.13 & 0.65 & 0.34 \\
\hline Difference in body condition score & 0.06 & 0.00 & -0.13 & -0.25 & 0.00 & 0.09 & 0.16 & 0.29 \\
\hline Feed efficiency (kg of milk/kg of DM) & 0.79 & 0.95 & 0.90 & 1.10 & 0.91 & 0.12 & 0.49 & 0.50 \\
\hline Feed cost (U\$/d) & 3.25 & 2.57 & 2.33 & 1.99 & 1.77 & 0.26 & - & - \\
\hline Reduction of food costs (\%) & 0.00 & 20.90 & 28.42 & 38.87 & 45.62 & 7.7 & - & - \\
\hline
\end{tabular}

BW, body weight; SEM, standard error of the mean; $\mathrm{p}$-value, probability; DM, dry matter.

1) a) $\hat{Y}=2.03+3.46^{*} X, R^{2}=0.93 ;{ }^{b)} \hat{Y}=356.4-46.75^{*} X, R^{2}=0.97$, where $X$ is the level of food restriction; $R^{2}$ is the coefficient of determination; ${ }^{*}$ significant by the $t$ test, at $1 \%$ probability.

2) Diet ad libitum, allowing $5 \%$ refusals regarding dry matter offer. 
et al [25] evaluated the productive performance of crossbred Holstein/Zebu cows from 100 to 150 days of lactation consuming different diets without restriction in the supply and verified that the DMI was about $33.0 \mathrm{~g} / \mathrm{kg}$ of BW $(15.7 \mathrm{~kg} / \mathrm{d})$. This value is similar to those that were observed in the present study $(15.88 \mathrm{~kg} / \mathrm{d})$. Only in the restriction levels of $2.25 \%$ and $2.0 \%$ did the DMI drop below what was estimated by the NRC [14]. Consequently, restriction of the diet supply by up to $2 \%$ of an animal's BW directly impacted the protein and energy intake of the animal, as well as the intake of other nutrients. However, the DM digestibility of the diet was not changed, with a mean of $592 \mathrm{~g} / \mathrm{kg}$ DM. This occurred because the unique variation factor was the quantity offered. Normally in digestive trials, treatment of ad libitum (3.39\% BW) feeding would reduce the digestibility rather than restricted feeding, because of less retention time in digestive tract comparing with low DMI [26]. However, this difference was only numerical in the order of $11.16 \%$ in ad libitum treatment $(3.39 \%$ BW) with the restriction of $2 \%$ of BW.

The ingestive behavior and the speed of passage in the digesta can modify the digestibility of nutrients because cows under restriction have more time for rumination compared to those without restriction, allowing for greater fractionation of the particles of the ruminal bolus, and favoring the degradation of the rumen microorganisms. However, this behavior related to the time spent ruminating the DM and the fibrous fraction was not altered with feed restriction, nor was the number of chews per bolus ruminated or the chewing time of the DM and NDFap affected.

The maintenance of these rumination characteristics throughout the different diet supply levels can help to explain the similarity in DM digestibility and fibrous fraction values; this was because the diet was unique, with the same chemical composition across the different levels of supply and caused a longer feeding time in animals subjected to feed restriction $[27,28]$. The highest values observed for $\mathrm{CP}$ digestibility were in animals with restricted feed, which may be related to the rate of passage of the digesta functioning better due to the lower intake of DM in these animals. Lower digestion rates may imply a longer exposure of protein fractions to the action of microorganisms and proteolytic enzymes, which increases the digestibility of the $\mathrm{CP}$ in the rumen or intestine [28]. However, there are several isolated and interacting factors that influence the digestibility of nutrients in the gastrointestinal tract of animals [24].

Feed restriction in lactating cows reduces the ingested nitrogen and nitrogen balance due to the lower consumption of $\mathrm{CP}$ but does not modify the efficiency of nitrogen use (mean of 26\%). Doska et al [29] reported that the nitrogen use efficiency can vary from $15 \%$ to $40 \%$ depending on the level of milk production and feeding practices. Plasma urea nitrogen was increased from $11.53 \mathrm{mg} / \mathrm{dL}$ (without restriction, 3.39\% of BW) to $17.23 \mathrm{mg} / \mathrm{dL}$ (2.0\% supply restriction). The increase in $\mathrm{CP}$ was not accompanied by an increase in the digestibility of the energy sources for the microorganisms of the rumen; with the quantitative restriction of food possibly hampering the use of rumen ammonia in the synthesis of microbial protein and increasing plasma urea nitrogen [28]. According to Doska et al [29], urea nitrogen and concentrations of nitrogen compounds in the plasma are related. In Brazilian conditions, values from 10.0 to $14.0 \mathrm{mg} / \mathrm{dL}$ of nitrogen in the plasma would represent the limits of dietary protein losses occurring. Thus, the restriction of dietary supply below $2.5 \%$ of DMI per BW increases the urea plasma concentration, which could indicate that there is a loss of protein occurring or an inefficient use of nutrients.

The reduction in the final BW of the cows with feed restriction is explained by the lower intake of nutrients, however, the body score (mean 3.76) and feed efficiency ( $0.93 \mathrm{~kg}$ milk/kg of ingested DM) were maintained in these animals. This behavior demonstrates the adaptability potential of crossbred cows under conditions of diet supply restriction. Roche et al [30] evaluated strategies for increasing the BCS of pre- and postpartum cows and verified that the BCS is a metabolic indicator of the energy balance of the animal and can be used as a dietary energy restriction strategy. Roche et al [30] suggested that the ideal BCS for Holstein cows varies from 2.75 to 3.25 for cows in the middle third of their lactation periods, indicating that the crossbred cows used in this study had reserves slightly above those recommended for purebred cows.

It is important to emphasize that, in addition to unaltered milk production and maintenance BCS of cows with a restriction in diet supply, production costs declined by up to $45.62 \%$ in relation to the control diet $(3.39 \% \mathrm{BW})$. This is very important since the profit margin within the dairy industry in Brazil is generally narrow. Moreover, the cost of the feed is greater than $50 \%$ of the total production cost. This strategy of restriction in the diet supply can be an alternative to make the production system feasible and to improve profitability. Therefore, the best restriction strategy can be evaluated within each milk production system. However, although there was no change in milk production or BCS in F1 Holstein/Zebu cows with diet restriction at $2 \% \mathrm{BW}$, there was a reduction in the milk production corrected for 3.5\% fat and final BW of the animals, which could compromise reproductive activity. In this sense, dietary restriction of no less than $2.5 \%$ BW would be recommended in the middle third of lactation, in view of the lower weight loss of the cows and reduction of the food cost by as much as $28.42 \%$ compared to diet ad libitum (control; 3.25 US\$/d).

\section{CONCLUSION}

The restriction of diet to as low as $2 \%$ of an animal's BW was 
effective in reducing food costs by $45.6 \%$. This restriction of diet may be adopted due to the availability of food, milk prices, and other factors that interfere with the production system. However, considering the observed BW loss and decrease in milk production corrected for $3.5 \%$ fat, a restriction of no less than $2.5 \% \mathrm{BW}$ is recommended.

\section{CONFLICT OF INTEREST}

We certify that there is no conflict of interest with any financial organization regarding the material discussed in the manuscript.

\section{ACKNOWLEDGMENTS}

To FAPEMIG for financial assistance and $\mathrm{CNPq}$ for the granting of scholarships, to INCT-Ciência Animal and EPAMIG. This study was financed in part by the Coordenação de Aperfeiçoamento de Pessoal de Nível Superior - Brasil (CAPES) - Finance Code 001.

\section{REFERENCES}

1. Canaza-Cayo AW, Cobuci JA, Lopes PS, et al. Genetic trend estimates for milk yield production and fertility traits of the Girolando cattle in Brazil. Livest Sci 2016;190:113-22. https:// doi.org/10.1016/j.livsci.2016.06.009

2. Santos SA, Valadares Filho SC, Detmann E, et al. Voluntary intake and milk production in F1 Holstein×zebu cows in confinement. Trop Anim Health Prod 2012;44:1303-10. https:// doi.org/10.1007/s11250-011-0072-2

3. Oliveira AS. Meta-analysis of feeding trials to estimate energy requirements of dairy cows under tropical condition. Anim Feed Sci Technol 2015;210:94-103. https://doi.org/10.1016/ j.anifeedsci.2015.10.006

4. Keogh K, Kenny DA, Cormican P, McCabe MS, Kelly AK, Waters SM. Effect of dietary restriction and subsequent Realimentation on the transcriptional profile of bovine skeletal muscle. PLoS One 2016;11:e0149373. https://doi.org/10.1371/ journal.pone. 0149373

5. Schütz KE, Cox NR, Macdonald KA, et al. Behavioral and physiological effects of a short-term feed restriction in lactating dairy cattle with different body condition scores at calving. J Dairy Sci 2013;96:4465-76. https://doi.org/10.3168/jds.20126507

6. Gabbi AM, McManus CM, Zanela MB, et al. Milk traits of lactating cows submitted to feed restriction. Trop Anim Health Prod 2016;48:37-43. https://doi.org/10.1007/s11250-0150916-2

7. Zanela MB, Fischer V, Ribeiro MER, et al. Unstable nonacid milk and milk composition of Jersey cows on feed restriction. Braz Agric Res 2006;41:835-40. http://dx.doi.org/10.1590/

\section{S0100-204X2006000500016}

8. Barbosa RS, Fischer V, Ribeiro MER, et al. Electrophoretic characterization of proteins and milk stability of cows submitted to feeding restriction. Braz Agric Res 2012;47:621-8. https://dx.doi.org/10.1590/S0100-204X2012000400019

9. Van Straten M, Friger M, Shpigel NY. Events of elevated somatic cell counts in high-producing dairy cows are associated with daily body weight loss in early lactation. J Dairy Sci 2009; 92:4386-94. https://doi.org/10.3168/jds.2009-2204

10. Latimer GW. AOAC International. Official methods of analysis of AOAC International. 19th ed. Gaithersburg, MD, USA: AOAC International; 2012.

11. Mertens DR. Gravimetric determination of amylase-treated neutral detergent fiber in feeds with refluxing in beaker or crucibles: collaborative study. J AOAC Int 2002;85:1217-40.

12. Licitra G, Hernandez TM, Van Soest PJ. Standardization of procedures for nitrogen fractionation of ruminant feeds. Anim Feed Sci Technol 1996;57:347-58. https://doi.org/10.1016/ 0377-8401(95)00837-3

13. Detmann E, Souza MA, Valadares Filho SC, et al. Methods for food analysis. Visconde do Rio Branco. Suprema; 2012.

14. Committee on Nutrient Requirements of Dairy Cattle, National Research Council. Nutrient requirements of dairy cattle, 7th rev. ed. Washington, DC, USA: National Academy Press; 2001.

15. Oliveira AS, Valadares RFD, Valadares Filho SC, et al. Microbial protein production, purine derivatives and urea excretion estimate in lactating dairy cows fed isoprotein diets with different non protein nitrogen compounds levels. Rev Bras Zootec 2001; 30:1621-9. http://dx.doi.org/10.1590/S1516-35982001000 600032

16. Chizzotti ML, Valadares Filho SC, Valadares RFD, et al. Intake, digestibility and nitrogen metabolism in Holstein cows with different milk production levels. Rev Bras Zootec 2007;36:13846. http://dx.doi.org/10.1590/S1516-35982007000100017

17. Broderick GA. Effects of varying dietary protein and energy levels on the production of lactating dairy cows. J Dairy Sci 2003;86:1370-81. https://doi.org/10.3168/jds.S0022-0302(03) 73721-7

18. Valadares Filho SC, Broderick GA, Valadares RF, Clayton MK. Effect of replacing alfalfa silage with high moisture corn on nutrient utilization and milk production. J Dairy Sci 2000;83: 106-14. https://doi.org/10.3168/jds.S0022-0302(00)74861-2

19. Rennó FP, Pereira JC, Leite CAM, et al. Bioeconomic evaluation of feeding strategies in milk production systems: 1 . Production per animal and per area. Braz J Anim Sci 2008;37: 743-53. http://dx.doi.org/10.1590/S1516-35982008000400022

20. Mezzalira JC, Carvalho PCF, Fonseca L, et al. Methodological aspects of ingestive behavior of grazing cattle. Rev Bras Zootec 2011;40:1114-20. http://dx.doi.org/10.1590/S151635982011000500024

21. Bürger PJ, Pereira JC, Queiroz AC, et al. Ingestive behavior in Holstein calves fed diets with different concentrate levels. 
Rev Bras Zootec 2000;29:236-42. http://dx.doi.org/10.1590/ S1516-35982000000100031

22. Sklan D, Ashkenazi R, Braun A, Devorin A, Tabori K. Fatty acids, calcium soaps of fatty acids, and cottonseeds fed to high yielding cows. J Dairy Sci 1992;75:2463-72. https://doi.org/ 10.3168/jds.S0022-0302(92)78008-4

23. Ferguson JD, Galligan DT, Thomsen N. Principal descriptors of body condition score in Holstein cows. J Dairy Sci 1994;77: 2695-703. http://dx.doi.org/10.3168/jds.S0022-0302(94) 77212-X

24. SAS Institute. SAS/STAT 9.2 User's guide. Cary, NC, USA: SAS Institute, Inc.; 2008.

25. Murta RM, Veloso CM, Pires AJV, et al. Intake, apparent digestibility, production, and composition of milk from cows fed diets with different sources of lipids. Rev Bras Zootec 2016; 45:56-62. http://dx.doi.org/10.1590/S1806-92902016000200 003

26. Menezes CCC, Valadares Filho SC, Magalhães FA, et al. Total and partial digestibility, rates of digestion obtained with rumenevacuation and microbial protein synthesis in bovines fed fresh or ensiled sugar cane and corn silage. Rev Bras Zootec
2011;40:1104-13. http://dx.doi.org/10.1590/S1516-359820 11000500023

27. Schwartzkopf-Genswein KS, Beauchemin KA, Gibb DJ, et al. Effect of bunk management on feeding behavior, ruminal acidosis and performance of feedlot cattle: a review. J Anim Sci 2003;81:E149-58. https://doi.org/10.2527/2003.8114_suppl_ 2E149x

28. Dado TG, Allen MS. Intake limitations, feeding behavior, and rumen function of cows challenged with rumen fill from dietary fiber or inert bulk. J Dairy Sci 1995;78:118-33. http://dx.doi. org/10.3168/jds.S0022-0302(95)76622-X

29. Doska MC, Silva DFF, Horst SA, Valloto AA, Rossi Junior P, Almeida R. Sources of variation in milk urea nitrogen in Paraná dairy cows. Rev Bras Zootec 2012;41:692-7. http://dx.doi.org/ 10.1590/S1516-35982012000300032

30. Roche JR, Heiser A, Mitchell MD, et al. Strategies to gain body condition score in pasture-based dairy cows during late lactation and the far-off nonlactating period and their interaction with close-up dry matter intake. J Dairy Sci 2017;100:172038. https://doi.org/10.3168/jds.2016-11591 